\title{
PENERAPAN AREA TRAFFIC CONTROL SYSTEM SEBAGAI IMPLEMENTASI TRANSPORTASI BERKELANJUTAN DI KOTA TEGAL
}

\author{
Pipit Rusmandani \\ Politeknik Keselamatan Transportasi Jalan \\ Pusat Penelitian dan Pengabdian \\ kepada Masyarakat (P3M) \\ Jln. Semeru No. 3, Kota Tegal, Jawa Tengah \\ pipit@pktj.ac.id
}

\author{
Riandy Sholeh Setiawan \\ Pemerintah Kota Tegal \\ andy_wates@yahoo.co.id
}

\begin{abstract}
The position of Tegal City in the North Coast Line (Pantura) of Central Java is very strategic, because it is the Hinterland for the surrounding area. This requires good conditions of roads and intersections. In this study, an attempt was made to apply coordinated signalized intersections, using the Area Traffic Control System, for 4 selected intersections. There are 3 alternatives proposed, namely Alternative I, which uses the Area Traffic Control System, Alternative II, which is autonomous control of intersections, and Alternative III, which does not need to coordinate the intersection. By using the Analytical Hierarchy Process method, respondents' support for Alternative I is $61.01 \%$, for Alternative II is $27.19 \%$, and for Alternative III is $12.12 \%$.
\end{abstract}

Keywords: intersection, signalized intersection, coordinated intersections, Area Traffic Control System

\begin{abstract}
Abstrak
Posisi Kota Tegal yang berada di Jalur Pantai Utara (Pantura) Jawa Tengah sangat strategis, karena merupakan Hinterland bagi daerah di sekitarnya. Hal ini membutuhkan kondisi ruas jalan dan simpang yang baik. Pada studi ini dicoba untuk menerapkan simpang-simpang bersinyal yang terkoordinasi, dengan menggunakan Area Traffic Control System, pada 4 simpang yang dipilih. Terdapat 3 alternatif yang diusulkan, yaitu Alternatif I, yaitu menggunakan Area Traffic Control System, Alternatif II, yaitu pengendalian persimpangan secara otonom, dan Alternatif III, yaitu tidak perlu ada pengendalian persimpangan. Dengan menggunakan metode Analytical Hierarchy Process didapat dukungan responden untuk Alternatif I sebesar 61,01\%, untuk Alternatif II sebesar 27,19\%, dan untuk Alternatif III sebesar 12,16\%.
\end{abstract}

Kata-kata kunci: simpang, simpang bersinyal, pengendalian simpang, Area Traffic Control System

\section{PENDAHULUAN}

Kota Tegal berada di Jalur Pantai Utara (Pantura) Jawa Tengah dan letaknya sangat strategis. Dengan letaknya tersebut, Kota Tegal merupakan penghubung jalur perekonomian lintas nasional dan lintas regional di wilayah Pantura, yaitu dari barat ke timur (JakartaTegal-Semarang-Surabaya) dengan wilayah tengah dan selatan Pulau Jawa (Jakarta-TegalPurwokerto-Yogyakarta-Surabaya) dan sebaliknya.

Di Kota Tegal terdapat lebih dari 300 persimpangan, yang penanganan simpangnya menggunakan Alat Pemberi Isyarat Lalu Lintas (APILL), berupa Traffic Light, dengan sejumlah 22 simpang bersifat otonom. Menurut Sebayang et al. (2015), secara teknis permasalahan persimpangan ini dapat menjadi potensi ketidaknyamanan dalam berlalu 
lintas, sehingga hal tersebut harus diminimalisasi dengan cara melakukan perbaikan manajemen pada pada simpang-simpang atau dengan mengintegrasikan simpang-simpang tersebut dalam satu sistem kawasan, yang biasa dikenal dengan nama Area Traffic Control System atau disingkat ATCS (Hendra et al., 2013).

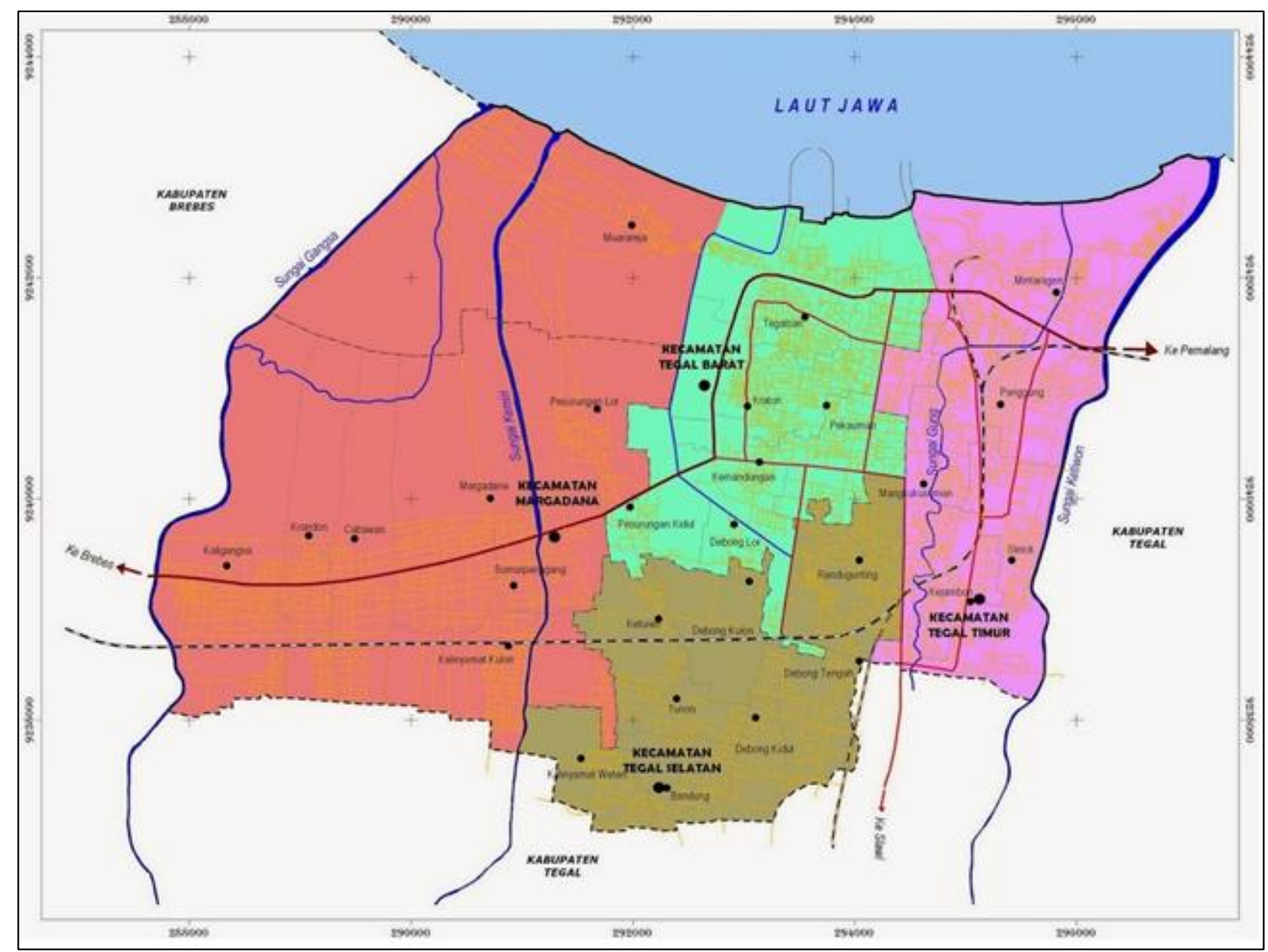

Gambar 1 Peta Administrasi Kota Tegal

Penerapan ATCS di Kota Tegal merupakan salah satu penerapan sistem transportasi berkelanjutan dan implementasi program smart city yang digagas oleh pemerintah dalam rangka peningkatan pelayanan kepada masyarakat, khususnya pengguna jalan. Penelitian ini mengambil studi kasus pada persimpangan yang menggunakan Alat Pemberi Isyarat Lalu Lintas, yang ada di Kota Tegal, terkait dengan kinerja persimpangan dan langkah-langkah perencanaan yang dapat dimanfaatkan dalam penerapan ATCS di Kota Tegal.

\section{METODE PENELITIAN}

Data yang digunakan pada kajian ini adalah data primer dan data sekunder. Data primer yang diperlukan diambil langsung di lapangan, dengan menggunakan angket atau kuesioner dan survei lapangan. Sedangkan data sekunder diperoleh dari instansi terkait di 
Pemerintah Kota Tegal, yaitu data Rencana Tata Ruang Wilayah (RTRW) dan peta jaringan jalan. Wawancara dilakukan dengan pejabat pemerintah di lingkungan Kota Tegal dan data volume lalu lintas diperoleh pada persimpangan yang menjadi lokasi kajian.

Analisis pada studi ini menggunakan Metode Analytical Hierarchy Process (AHP). Bagan alir kajian ini disajikan pada Gambar 2.

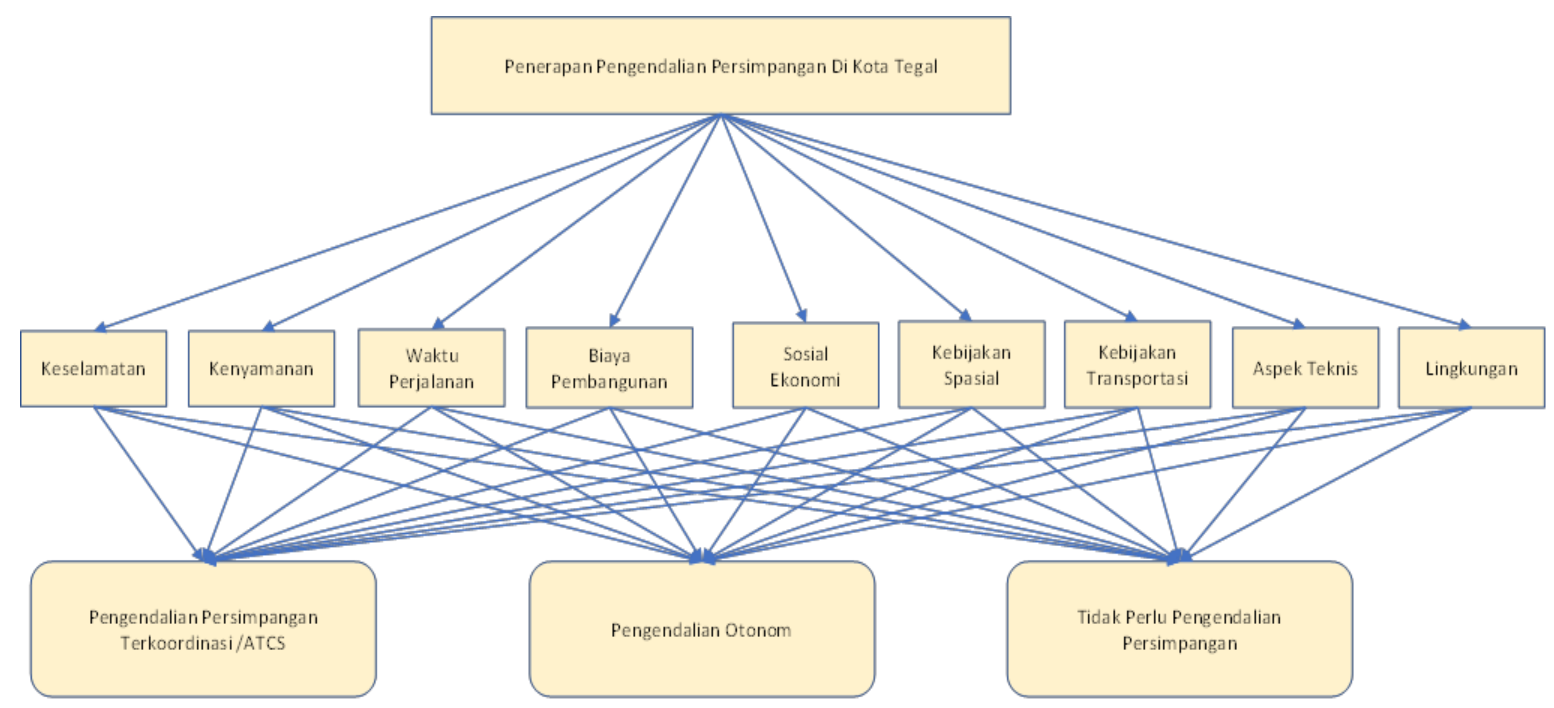

Gambar 2 Bagan Penentuan Penerapan Pengendalian Persimpangan

Pada penelitian ini kriteria yang digunakan adalah keselamatan, kenyamanan, waktu perjalanan, biaya pembangunan, sosial ekonomi, kebijakan spasial, kebijakan transportasi, aspek teknis, dan kriteria lingkungan. Sedangkan alternatif-alternatif yang digunakan adalah Alternatif I (Pengendalian Persimpangan Terkoordinasi/ATCS), Alternatif II (Pengendalian Otonom), dan Alternatif III (Tidak Perlu Pengendalian Persimpangan).

\section{HASIL DAN PEMBAHASAN}

Simpang-simpang yang akan dikaji adalah 4 simpang yang berada di tengah kota, dengan jarak antarsimpang yang relatif berdekatan, dengan jarak total sebesar 1.300 meter. Keempat simpang tersebut adalah Simpang Tiga Yogya, Simpang Tiga Gili Tugel, Simpang Empat Jakarta, dan Simpang Empat Tumpuk (lihat Gambar 3). Rangkuman data simpangsimpang tersebut dapat dilihat pada Tabel 1.

Pada kondisi eksisting, diketahui bahwa waktu siklus rata-rata berada pada kisaran (45-90) detik. Hal ini masih berada dalam standar waktu yang ditetapkan.

Kinerja simpang-simpang yang diamati dapat dilihat pada Tabel 2. Keempat simpang yang dikaji Derajat Kejenuhan lebih besar daripada 0,5, dan berdasarkan tundaan rata-rata, ketiga simpang masuk Kategori E, selain Simpang Tumpuk yang termasuk Kategori D. 


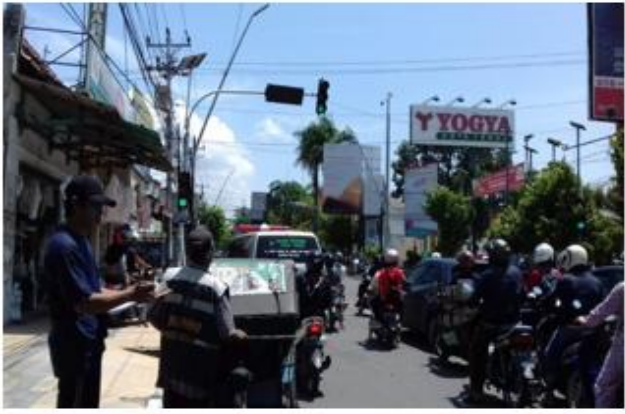

S.3 Yogya Mall

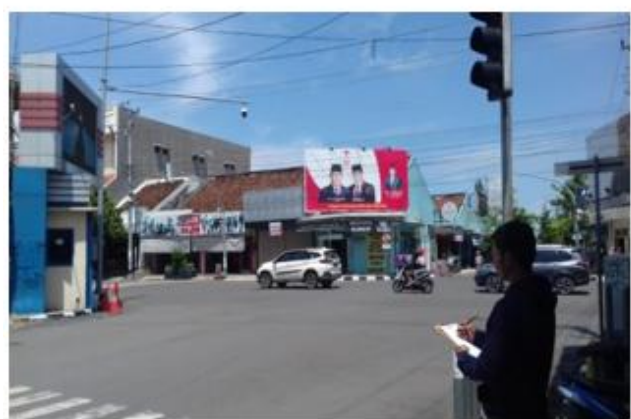

S.4 Jakarta

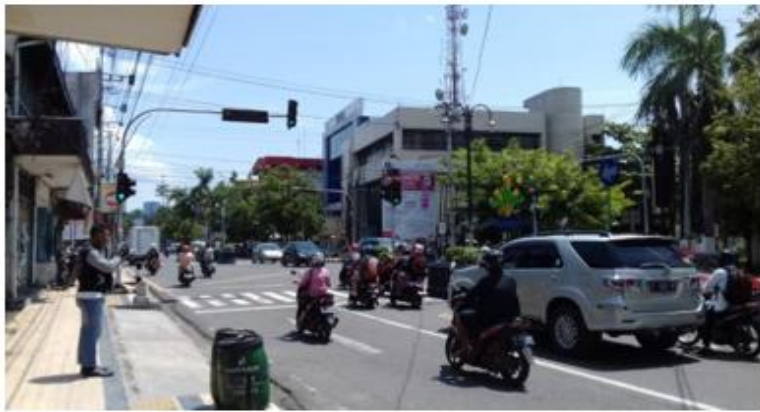

S.3 Gili Tugel

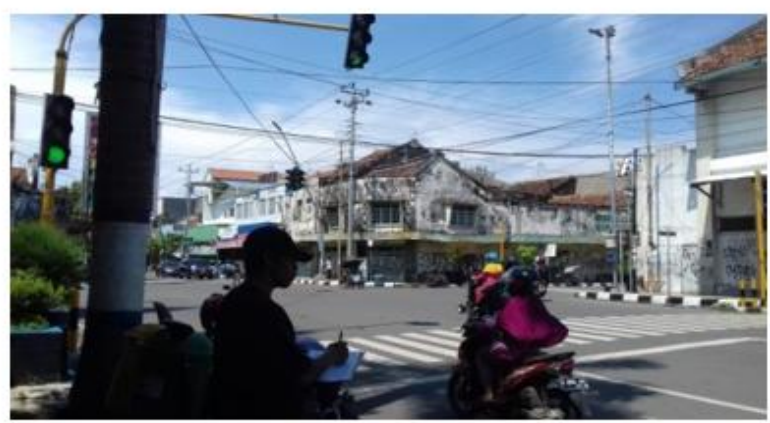

S.4 Tumpuk

Gambar 3 Lokasi Simpang yang Dikaji

Tabel 1 Siklus dan Waktu Hijau Simpang Bersinyal

\begin{tabular}{|c|c|c|c|c|c|c|}
\hline \multirow[t]{2}{*}{ No. } & \multirow[t]{2}{*}{ Simpang } & \multirow[t]{2}{*}{ Ruas/Kaki Simpang } & $\begin{array}{l}\text { Nilai Arus } \\
\text { Jenuh } \\
\text { Disesuaikan }\end{array}$ & $\begin{array}{l}\text { Waktu } \\
\text { Hijau }\end{array}$ & Siklus & Kapasitas \\
\hline & & & $\mathrm{S}$ & $\mathrm{g}$ & c & $\mathrm{C}$ \\
\hline \multirow[t]{3}{*}{1} & S.3 Yogya & Jln. A.R. Hakim & 2809 & 23 & 88 & 734 \\
\hline & & Jln. R.A. Kartini & 2809 & 21 & 88 & 670 \\
\hline & & Jln. A.R. Hakim & 3043 & 31 & 88 & 1072 \\
\hline \multirow[t]{3}{*}{2} & S.3 Gili Tugel & Jln. P. Diponegoro & 3043 & 23 & 77 & 909 \\
\hline & & Jln. A.R. Hakim & 3043 & 26 & 77 & 1027 \\
\hline & & Jln. Jendral Sudirman & 3277 & 19 & 77 & 809 \\
\hline \multirow[t]{4}{*}{3} & S.4 Jakarta & Jln. Ahmad Yani & 3277 & 19 & 87 & 716 \\
\hline & & Jln. Kh. Mansyur & 2809 & 14 & 87 & 452 \\
\hline & & Jln. P. Diponegoro & 2809 & 24 & 87 & 775 \\
\hline & & Jln. Hos Cokroaminoto & 2341 & 14 & 87 & 377 \\
\hline \multirow[t]{4}{*}{4} & S.4 Tumpuk & Jln. Veteran & 2341 & 19 & 48 & 926 \\
\hline & & Jln. Setia Budi & 1872 & 16 & 48 & 624 \\
\hline & & Jln. Ahmad Yani & 3979 & 19 & 48 & 1575 \\
\hline & & Jln. D.I. Panjaitan & 1872 & 16 & 48 & 624 \\
\hline
\end{tabular}

\section{Pengendalian Persimpangan dengan Metode Analytical Hierarchy Process}

Metode Analytical Hierarchy Process (AHP) digunakan untuk mengetahui prioritas pengendalian persimpangan pada jalan di Kota Tegal yang melibatkan stakeholder dan akademisi melalui wawancara. Dari wawancara juga diketahui bahwa diperlukan penyediaan lajur sepeda. 
Kriteria yang digunakan adalah keselamatan, kenyamanan, waktu perjalanan, biaya pembangunan, sosial ekonomi, kebijakan spasial, kebijakan transportasi, aspek teknis, dan kriteria lingkungan. Sesuai dengan konsep AHP, kepentingan pada kuesioner dibuat dengan skala 1 sampai dengan 9. Hasil yang diperoleh dari kuesioner ini diolah dengan menggunakan Microsoft Excel.

Tabel 2 Kinerja Simpang Bersinyal

\begin{tabular}{ccccccc}
\hline No. & Simpang & $\begin{array}{c}\text { Volume Puncak } \\
\text { Simpang }\end{array}$ & $\begin{array}{c}\text { Rasio } \\
\text { Arus }\end{array}$ & $\begin{array}{c}\text { Derajat } \\
\text { Kejenuhan } \\
\text { Rata-Rata }\end{array}$ & $\begin{array}{c}\text { Panjang } \\
\text { Antrian } \\
\text { Rata-Rata }\end{array}$ & $\begin{array}{c}\text { Tundaan } \\
\text { Rata-Rata }\end{array}$ \\
\cline { 2 - 6 } & (Maks) & $($ FR) & $($ DS $)$ & $(\mathrm{m})$ & (det/kend) \\
\hline 1 & S.3 Yogya & 691 & 0,63 & 0,75 & 42,01 & 51,23 \\
2 & S.3 Gili Tugel & 473 & 0,54 & 0,60 & 39,76 & 41,69 \\
3 & S.4 Jakarta & 555 & 0,60 & 0,75 & 32,15 & 53,95 \\
4 & S.4 Tumpuk & 947 & 0,47 & 0,59 & 27,10 & 29,62 \\
\hline
\end{tabular}

\section{Proses Pengembangan Instrumen Penelitian}

Pada penelitian ini digunakan uji validitas dan uji reliabilitas, yaitu dengan melakukan perhitungan nilai Random Consistency (CR). Bila nilai CR kurang dari 0,1, hasil dapat dikatakan valid dan dapat dipertanggungjawabkan. Sebaliknya bila nilai CR lebih besar daripada 0,1 , hasil dinyatakan tidak valid dan tidak dapat dipertanggungjawabkan.

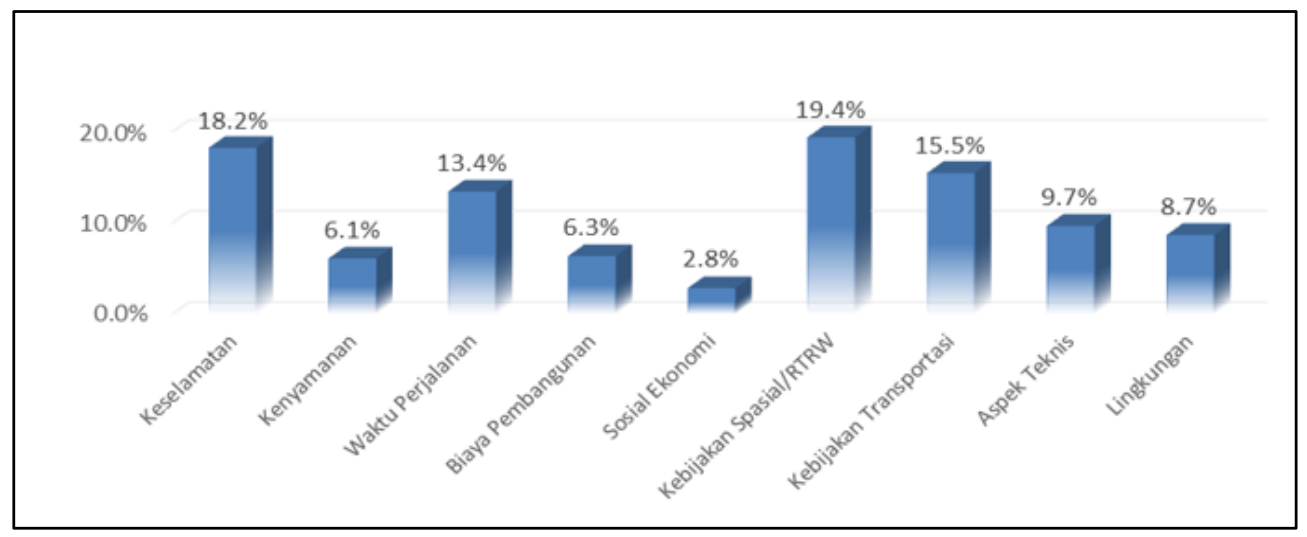

Gambar 4 Diagram Pemilihan Kriteria Pengendalian Persimpangan di Kota Tegal

Pada Gambar 4 dan Tabel 3 terlihat bahwa kriteria yang dipilih responden, dari yang paling tinggi sampai ke yang paling rendah, adalah Kebijakan Spasial/RTRW sebesar 19,4\%, Keselamatan sebesar 18,2\%, Kebijakan Transportasi sebesar 15,5\%, Waktu Tempuh sebesar 13,4\%, Aspek Teknis sebesar 9,7\%, Aspek Lingkungan sebesar 8,7\%, Biaya Pembangunan sebesar 6,3\%, Kenyamanan sebesar 6,1\%, dan Sosial Ekonomi sebesar 2,8\%. Nilai rata-rata CR adalah 0,0923 atau lebih kecil daripada 0,1, sehingga dapat dinyatakan bahwa seluruh responden kosisten. Nilai CR pada subkriteria lebih kecil daripada 0,1 (lihat Tabel 4). Terlihat juga bahwa pemilihan prioritas pengendalian persimpangan di Kota Tegal adalah Alternatif I (ATCS) sebesar 60,65\%, Alternatif II (pengendalian persimpangan secara otonom pada tiap simpang) sebesar $27,19 \%$, dan Alternatif III (tidak perlu ada pengendalian persimpangan) sebesar $12,16 \%$. 


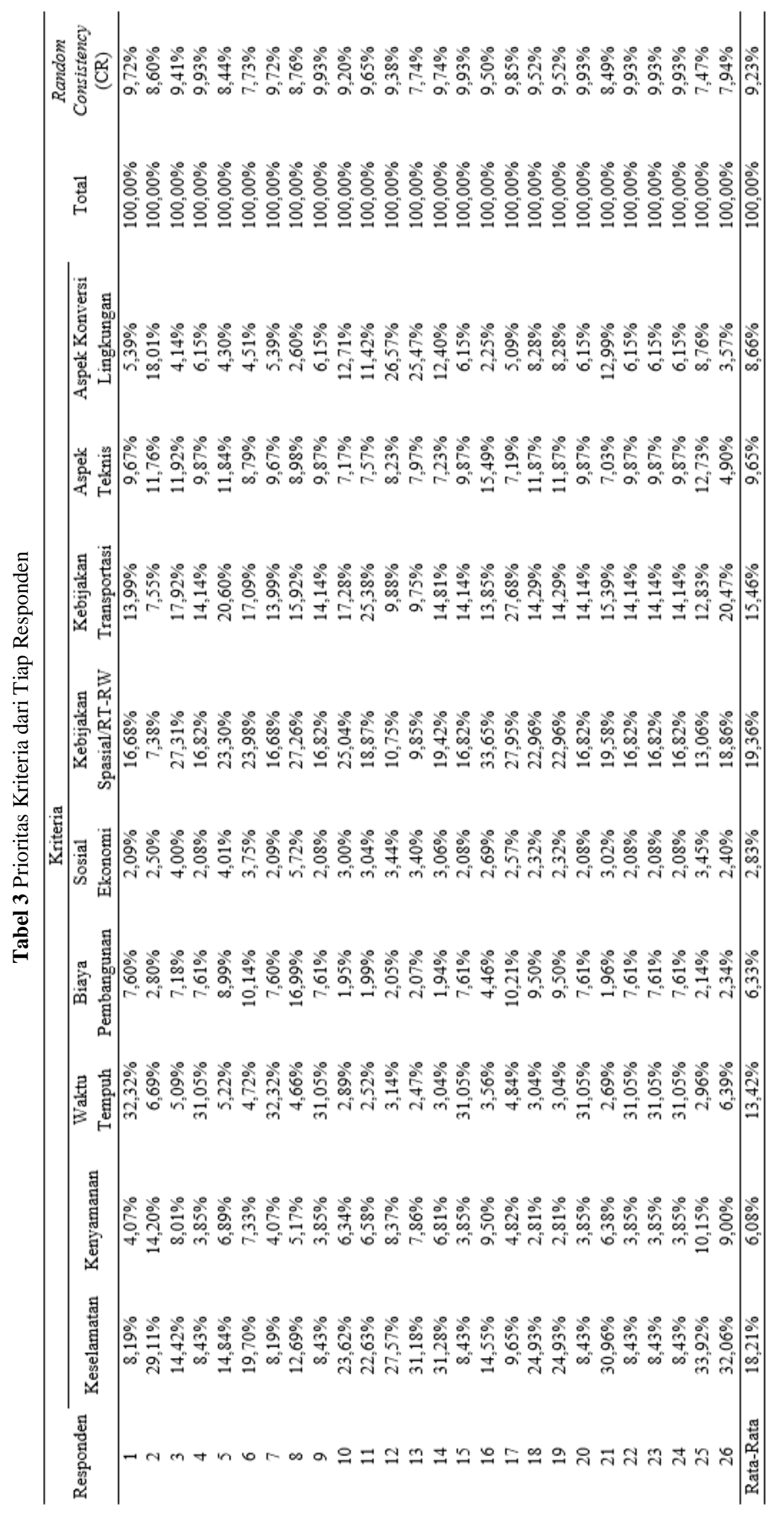


Tabel 4 Hasil Analisis terhadap Alternatif-Alternatif

\begin{tabular}{|c|c|c|c|c|c|c|}
\hline \multirow{2}{*}{ Kriteria } & \multirow{2}{*}{$\begin{array}{l}\text { Bobot } \\
\text { Kriteria }\end{array}$} & \multicolumn{3}{|c|}{ Alternatif } & \multirow{2}{*}{$\begin{array}{c}\text { Total } \\
\text { Alternatif }\end{array}$} & \multirow{2}{*}{$\begin{array}{c}\text { Random } \\
\text { Consistency } \\
\text { (CR) }\end{array}$} \\
\hline & & I & II & III & & \\
\hline Keselamatan & $18,2 \%$ & $68,94 \%$ & $22,67 \%$ & $8,39 \%$ & 1 & 0,04 \\
\hline Kenyamanan & $6,1 \%$ & $67,79 \%$ & $22,51 \%$ & $9,69 \%$ & 1 & 0,04 \\
\hline Waktu Tempuh & $13,4 \%$ & $66,71 \%$ & $23,08 \%$ & $10,21 \%$ & 1 & 0,04 \\
\hline Biaya Pembangunan & $6,3 \%$ & $14,70 \%$ & $52,90 \%$ & $38,22 \%$ & 1 & 0,02 \\
\hline Sosial Ekonomi & $2,8 \%$ & $63,02 \%$ & $25,66 \%$ & $11,32 \%$ & 1 & 0,05 \\
\hline Kebijakan Spasial/RTRW & $19,4 \%$ & $58,96 \%$ & $29,43 \%$ & $11,61 \%$ & 1 & 0,03 \\
\hline Kebijakan Transportasi & $15,5 \%$ & $59,02 \%$ & $28,99 \%$ & $11,99 \%$ & 1 & 0,06 \\
\hline Aspek Teknis & $9,7 \%$ & $66,97 \%$ & $23,26 \%$ & $9,77 \%$ & 1 & 0,05 \\
\hline Aspek Konservasi Lingkungan & $8,7 \%$ & $65,50 \%$ & $24,23 \%$ & $10,27 \%$ & 1 & 0,03 \\
\hline Bobot Alternatif & & $60,65 \%$ & $27,19 \%$ & $12,16 \%$ & 1 & 0,04 \\
\hline
\end{tabular}

\section{Perencanaan Simpang Terkoordinasi}

Dari data kondisi eksisting diketahui bahwa waktu siklus untuk Simpang Tiga Yogya Mall sebesar 88 detik, Simpang Tiga Gili Tugel 77 detik, Simpang Empat Jakarta 87 detik, dan Simpang Empat Tumpuk 48 detik. Data ini menunjukkan bahwa ruas tersebut tidak memenuhi syarat untuk simpang koordinasi, karena memiliki waktu siklus yang berbedabeda. Untuk perlu diketahui terlebih dahulu kecepatan platoon pada ruas tersebut, sehingga waktu dari simpang satu ke simpang lainnya dapat ditentukan.

Untuk perencanaan simpang koordinasi, kecepatan maksimum yang digunakan adalah $40 \mathrm{~km} / \mathrm{jam}$. Hal ini didasarkan pada regulasi yang ada, yang menyatakan bahwa bahwa batas kecepatan maksimum untuk ruas jalan dalam kota adalah $40 \mathrm{~km} / \mathrm{jam}$. Hal ini juga mempertimbangkan bahwa dengan kecepatan lambat akan didapat offset yang cukup panjang sehingga kendaraan terakhir dalam platoon masih memiliki kesempatan untuk mendapat sinyal hijau.

\section{Waktu Tempuh dari Selatan ke Utara}

Pada studi ini dilakukan 6 perencanaan waktu siklus baru. Setiap rencana didasarkan pada waktu siklus salah satu simpang yang telah dihitung. Kemudian simpang-simpang yang lain mengikuti waktu siklus tersebut agar didapat waktu siklus yang sama. Sebagai contoh adalah untuk Skema 1, yang menerapkan waktu siklus Simpang Yogya sebesar 88 detik, untuk diterapkan ke semua simpang. Kemudian dilakukan untuk skema-skema yang lain. Skema-skema pengaturan waktu siklus tersebut adalah sebagai berikut:

1) Skema 1: waktu siklus semua simpang sesuai Simpang Yogya Mall;

2) Skema 2: waktu siklus semua simpang sesuai Simpang Gili Tugel;

3) Skema 3: waktu siklus semua simpang sesuai Simpang Jakarta;

4) Skema 4: waktu siklus semua simpang sesuai Simpang Tumpuk;

5) Skema 5: waktu siklus semua simpang menggunakan waktu maksimal (130 detik);

6) Skema 6: waktu siklus semua simpang dinamik.

Hasil untuk Skema 6 menunjukkan bahwa dapat terjadi suatu koordinasi antarsimpang, seperti yang dapat dilihat pada Gambar 5. 


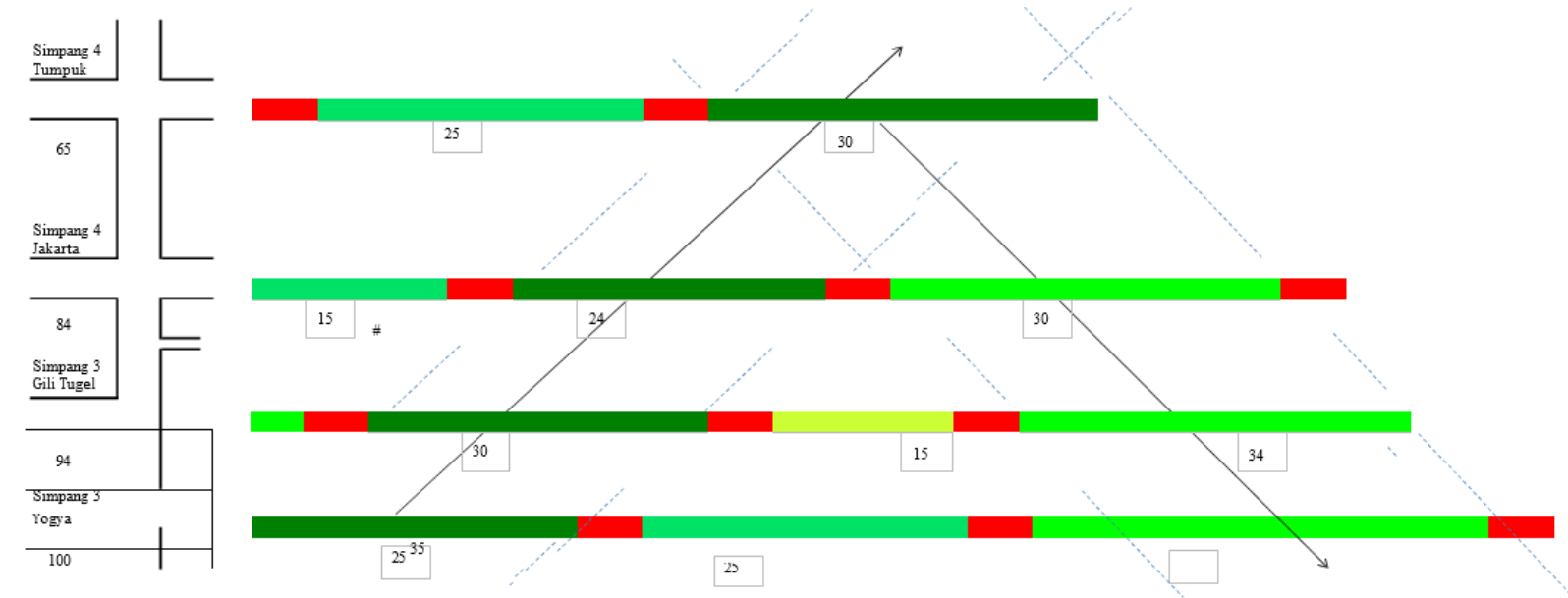

Gambar 5 Simulasi Koordinasi Simpang Skema 6

\section{KESIMPULAN}

Berdasarkan analisis yang telah dilakukan dapat disimpulkan bahwa dari alternatifalternatif prioritas pengendalian persimpangan di Kota Tegal, diperoleh Alternatif I, yaitu menggunakan ATCS, sebesar 60,65\%, Alternatif II, yaitu pengendalian persimpangan secara otonom, sebesar 27,19\%, dan Alternatif III, yaitu tidak perlu ada pengendalian persimpangan, sebesar $12,16 \%$. Waktu siklus yang koordinasi untuk keempat simpang yang ditinjau dilakukan dengan menentukan waktu siklus yang sama terlebih dahulu. Dari enam rencana, dipilih waktu siklus berkinerja terbaik yang durasi waktunya bervariasi. Koordinasi sinyal pada studi ini dilakukan dengan menggunakan waktu offset yang telah didapat dengan menggunakan kecepatan maksimum yang diizinkan dalam kota, yaitu 40 km/jam.

\section{DAFTAR PUSTAKA}

Hendra, Y.N.R., Illahi, A., dan Irawan, M.Z. 2013. Optimalisasi Penerapan ATCS (Area Traffic Control System) dalam Pengoperasian Trans Jogja Bus Priority pada Simpang Bersinyal. The $16^{\text {th }}$ FSTPT International Symposium, Universitas Muhammadiyah Surakarta, Surakarta.

Sebayang, N., Sulistyo, H., Djakfar, L., dan Wicaksono, A. 2015. Pengembangan Model Optimasi Offset Sinyal Lampu Isyarat Lalu Lintas pada Jaringan ATCS (Area Traffic Control System) Berbentuk Grid Menggunakan Model Transmisi Sel (Cell Transmission Model). The $18^{\text {th }}$ FSTPT International Symposium, Universitas Lampung, Bandar Lampung. 